\title{
WINTER 2021
}

\section{The}

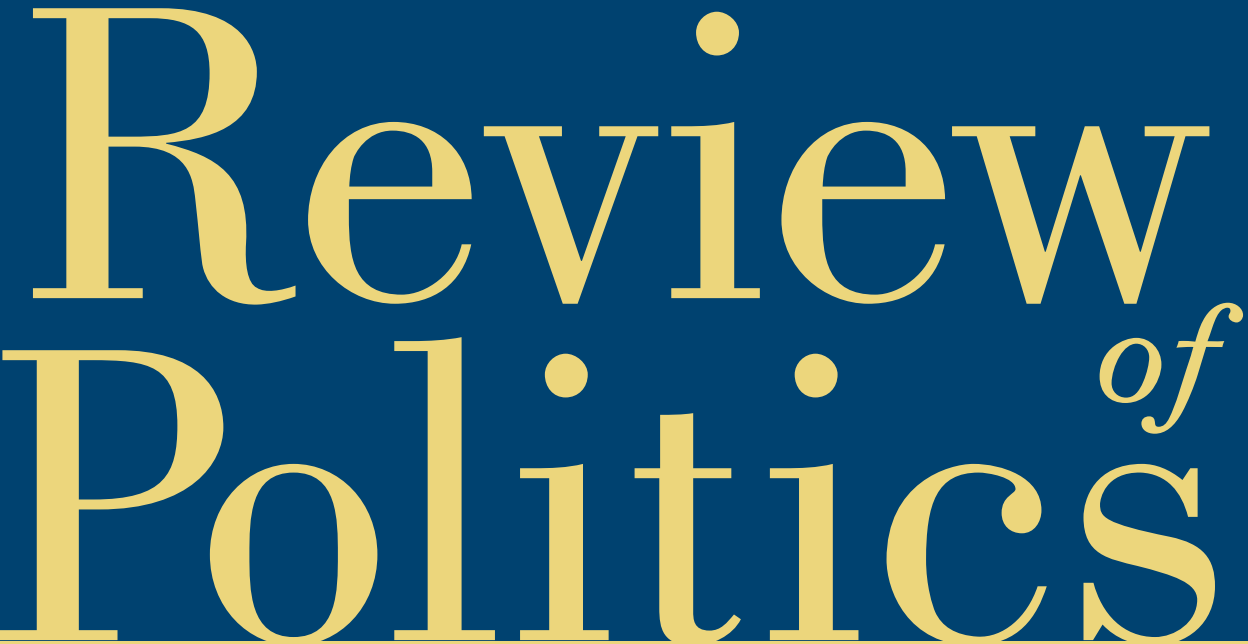

ARTICLES

Ross Mittiga, "Ranking the Regimes in Aristotle's Politics:

The Four-Principles Approach"

Salih Emre Gerçek, “Alexis de Tocqueville’s Reluctant 'Democratic

Language"

Sara Henary, "Anthony Trollope: Novelist of the 'Democratic

Revolution""

Christopher Nadon, "Leo Strauss's First Brush with Xenophon:

"The Spirit of Sparta or the Taste of Xenophon"

Adrian Blau, "How Should We Categorize Approaches to the History

of Political Thought?" 


\title{
THE REVIEW OF POLITICS
}

Editor

RUTH ABBEY

Book Review Editor

SUSAN D. COLLINS

Editorial Coordinator

KELLI BROWN

$\begin{array}{cc} & \text { Editorial Board } \\ \text { Ronald Beiner } & \text { Arlene Saxonhouse } \\ \text { University of Toronto } & \text { University of Michigan } \\ \text { Simone Chambers } & \text { Denise Schaeffer } \\ \text { University of California, Irvine } & \text { College of the Holy Cross } \\ \text { Fred Dallmayr } & \text { William E. Scheuerman } \\ \text { University of Notre Dame } & \text { Indiana University, Bloomington } \\ \text { Elizabeth Frazer } & \text { John T. Scott } \\ \text { University of Oxford } & \text { University of California, Davis } \\ \text { Leslie Goldstein } & \text { Steven B. Smith } \\ \text { University of Delaware } & \text { Yale University } \\ \text { Sungmoon Kim } & \text { Peter Steinberger } \\ \text { City University of Hong Kong } & \text { Reed College } \\ \text { A. James McAdams } & \text { Vickie Sullivan } \\ \text { University of Notre Dame } & \text { Tufts University } \\ \text { Daniel Philpott } & \text { Paul Weithman } \\ \text { University of Notre Dame } & \text { University of Notre Dame }\end{array}$

Copyeditor: LES HARRIS

Editorial Interns: Samuel Piccolo and Abigail M. Staysa

Former Editors

\author{
Waldemar Gurian \\ M.A. Fitzsimons \\ Thomas Stritch \\ Frederick J. Crosson
}

\author{
Donald P. Kommers \\ Walter Nicgorski \\ Catherine Zuckert
}

The Review of Politics publishes primarily philosophical and historical studies of politics, especially those in political theory and American political thought. The journal also includes thoughtful scholarly reflections on all aspects of politics-laws, and institutions, international relations, comparative politics - as well as literary reflections on politics or political interpretations of literature. 


\section{TABLE OF CONTENTS WINTER 2021}

Vol. 83

WINTER 2021

No. 1

Ross Mittiga

Ranking the Regimes in Aristotle's Politics:

The Four-Principles Approach $\ldots \ldots \ldots \ldots \ldots \ldots \ldots$

Salih Emre Gerçek

Alexis de Tocqueville's Reluctant

"Democratic Language" ...................... 21

Sara Henary

Anthony Trollope: Novelist of the

“Democratic Revolution" ........................445

Christopher Nadon

Leo Strauss's First Brush with Xenophon: "The Spirit of

Sparta or the Taste of Xenophon" ................69

Adrian Blau

How Should We Categorize Approaches to the History of

Political Thought?

Reviews:

Gianna Englert

Review of Tracy B. Strong's Learning One's Native Tongue:

Citizenship, Contestation, and Conflict in America.

Aaron J. Ley

Review of Kimberly K. Smith's The Conservation Constitution:

The Conservation Movement and Constitutional Change, 1870-1930 . . . 117

Säde Hormio

Review of Alasia Nuti's Injustice and the Reproduction of History:

Structural Inequalities, Gender and Redress . . . . . . . . . . . . . . . . 120

Christopher C. Robinson

Review of John G. Gunnell's Conventional Realism and Political

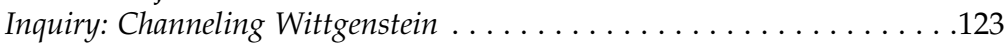

John von Heyking

Review of Paul Ludwig's Rediscovering Political Friendship: Aristotle's

Theory and Modern Identity, Community, and Equality . . . . . . . . . . 125

Jonathan Gondelman

Review of Paul A. Rahe's Sparta's First Attic War: The Grand

Strategy of Classical Sparta, 478-446 B.C. . . . . . . . . . . . . . . . . 128

S.N. Jaffe

Review of Gerald M. Mara's Between Specters of War and Visions of

Peace: Dialogic Political Theory and the Challenges of Politics 
Carl J. Richard

Review of Tim Stuart-Buttle's From Moral Theology to Moral

Philosophy: Cicero and Visions of Humanity from Locke to Hume. . . . . . 133

Michael C. Hawley

Review of Cary J. Nederman's The Bonds of Humanity: Cicero's

Legacies in European Social and Political Thought, ca. 1100-ca. 1550 . . . 136

Bernd Renner

Review of Timothy Haglund's Rabelais's Contempt for Fortune:

Pantagruelism, Politics, and Philosophy....................139

Devin Stauffer

Review of Jeffrey R. Collins's In the Shadow of Leviathan: John Locke

and the Politics of Conscience . . . . . . . . . . . . . . . . . . . . . . . 141

Benjamin Storey

Review of Michael Locke McLendon's The Psychology of Inequality:

Rousseau's Amour-Propre. . . . . . . . . . . . . . . . . . . . . . . . . 144

Peter Minowitz

Review of Ryan Patrick Hanley's Our Great Purpose: Adam Smith on Living a Better Life . . . . . . . . . . . . . . . . . . . . . . . . . . . .146

Simon Townsend

Review of Jeffrey Metzger's The Rise of Politics and Morality in

Nietzsche's "Genealogy": From Chaos to Conscience. . . . . . . . . . . . . . . .149 
Subscription Information: The Review of Politics (ISSN 0034-6705) is published quarterly in February, May, August and November by Cambridge University Press, One Liberty Plaza, 20th Floor, New York, NY 10006, USA/University Printing House, Shaftesbury Road, Cambridge CB2 8BS, UK for the University of Notre Dame. Annual subscription rates for Volume 83 (2021): Institutional subscription rates, print and online: US $\$ 229.00$ in the USA, Canada, and Mexico; UK $£ 135.00$ + VAT elsewhere. Institutional subscription rates, online only: US $\$ 189.00$ in the USA, Canada, and Mexico; UK $£ 116.00$ + VAT elsewhere. Institutional subscription rates, print only: US \$218.00 in the USA, Canada, and Mexico; UK $£ 132.00+$ VAT elsewhere. Individual subscription rates, print only: US $\$ 54.00$ in the USA, Canada, and Mexico; UK $£ 31.00$ + VAT elsewhere. Single part rates: US $\$ 63.00$ in the USA, Canada, and Mexico; UK £38.00. Correspondence concerning subscriptions should be sent to: Cambridge University Press, One Liberty Plaza, 20th Floor, New York, NY 10006, USA for customers in the USA, Canada, or Mexico. Customers elsewhere should contact: Cambridge University Press, University Printing House, Shaftesbury Road, Cambridge CB2 8BS, UK.

Editorial Office: All correspondence concerning submissions and manuscripts under review should be sent to The Review of Politics, University of Notre Dame, 2005 Jenkins Nanovic Halls, Notre Dame, IN 46556-7000. Phone: 574-631-6623. Email: ROP.Editor.1@nd.edu. Website: reviewofpolitics.nd.edu

Abstracting and Indexing Information: Articles in The Review of Politics are indexed in the International Index to Periodicals and the Catholic Periodicals and Literature Index; abstracted in the International Political Science Abstracts; and abstracted and indexed in ABC POL. SCI., Historical Abstracts, Social Science Index (also available in the electronic versions), Book Review Index, and International Bibliography of the Social Sciences.

Copyright (C) 2021 University of Notre Dame. All rights reserved. No part of this publication may be reproduced, in any form or by any means, electronic, photocopy, or otherwise, without permission in writing from Cambridge University Press, Rights and Permissions Manager, One Liberty Plaza, 20th Floor, New York, NY 10006, USA. For further information see http://us.cambridge/org/information/rights/

Periodicals postage paid in New York, NY and additional mailing offices. Postmaster: Send address changes to The Review of Politics, Cambridge University Press, One Liberty Plaza, 20th Floor, New York, NY 10006, USA.

Photocopying information for users in the U.S.A.: the Item-Fee Code for the publication (0034-6705/18 \$9.00+.10) indicates that copying for internal or personal use beyond that permitted by Sec. 107 or 108 of the U.S. Copyright Law is authorized for users duly registered with the Copyright Clearance Center (CCC) provided that the appropriate remittance of $\$ 9.00$ per article is paid directly to CCC, 222 Rosewood Drive, Danvers, MA 01923. Specific written permission must be obtained for all other copying. 